\title{
An Archival and Archaeological Study for the Relocation of Three Historic Homes in Hemisfair Park, San Antonio, Texas
}

Edgar D. Johnson

Center for Archaeological Research

I. Waynne Cox

Center for Archaeological Research

Follow this and additional works at: https://scholarworks.sfasu.edu/ita

Part of the American Material Culture Commons, Archaeological Anthropology Commons, Environmental Studies Commons, Other American Studies Commons, Other Arts and Humanities Commons, Other History of Art, Architecture, and Archaeology Commons, and the United States History Commons

Tell us how this article helped you.

This Article is brought to you for free and open access by the Center for Regional Heritage Research at SFA ScholarWorks. It has been accepted for inclusion in Index of Texas Archaeology: Open Access Gray Literature from the Lone Star State by an authorized editor of SFA ScholarWorks. For more information, please contact cdsscholarworks@sfasu.edu. 
An Archival and Archaeological Study for the Relocation of Three Historic Homes in Hemisfair Park, San Antonio, Texas

\section{Creative Commons License}

\section{(c) (1) \&}

This work is licensed under a Creative Commons Attribution-NonCommercial 4.0 International License 


\title{
AN ARCHIVAL AND ARCHAEOLOGICAL STUDY FOR THE RELOCATION OF THREE HISTORIC HOMES IN HEMISFAIR PARK, SAN ANTONIO, TEXAS
}

\author{
Edgar D. Johnson and I. Waynne Cox
}

Robert J. Hard and C. Britt Bousman, Principal Investigators

\author{
- copyright
}

Center for Archaeological Research

The University of Texas at San Antonio

Archaeological Survey Report, No. 241 
The following information is provided in accordance with the General Rules of Practice and Procedure, Chapter 41.11 (Investigative Reports), Texas Antiquities Committee:

1. Type of investigation: Archival

2. Project name: Historic home relocation

3. County: Bexar

4. Principal investigators: Robert J. Hard and C. Britt Bousman

5. Name and location of sponsoring agency: Kell Muñoz Wigodsky, Inc., 800 N. Loop 410, 700 North Tower, San Antonio, Texas 78216

6. Texas Antiquities Committee Permit No.: n/a

7. Published by the Center for Archaeological Research, The University of Texas at San Antonio, San Antonio, Texas 78249-0658, 1995.

A list of publications offered by the Center for Archaeological Research can be obtained by sending $\$ 1.00$ to the Center for Archaeological Research, The University of Texas at San Antonio, 6900 N. Loop 1604 West, San Antonio, Texas 78249-0658. 


\begin{abstract}
The Center for Archaeological Research contracted with Kell Muñoz Wigodsky, Inc., to undertake an archival study of HemisFair Park. Three historic standing structures will be moved to three vacant lots in the park. Archival research demonstrated that two of the three structures-the Wietzel and Amaya houses-were the first buildings on the lots, while the third structure-the O.K. Bar-was in place by 1896 and was the first substantial structure on the lot. The Wietzel and Amaya houses will be moved to lots that have

never had buildings. The $\mathrm{O}$. $\mathrm{K}$. Bar will be moved to a lot that has had two structures. The earlier structure on this lot was destroyed by enlarging South Alamo Street, and the later structure was built between 1896 and 1904 .

It is unlikely that moving the structures will have an adverse effect on significant archaeological resources. However, the moves should be monitored to insure significant archaeological resources are not disturbed.
\end{abstract}




\section{CONTENTS}

ABSTRACT $\ldots \ldots \ldots \ldots \ldots \ldots \ldots \ldots \ldots \ldots \ldots \ldots \ldots \ldots \ldots \ldots$

FIGURES $\ldots \ldots \ldots \ldots \ldots \ldots \ldots \ldots \ldots \ldots \ldots \ldots \ldots \ldots \ldots \ldots$ iii

ACKNOWLEDGMENTS $\ldots \ldots \ldots \ldots \ldots \ldots \ldots \ldots \ldots \ldots \ldots \ldots$ iv

INTRODUCTION $\ldots \ldots \ldots \ldots \ldots \ldots \ldots \ldots \ldots \ldots \ldots \ldots \ldots \ldots \ldots \ldots \ldots$

AREA HISTORY $\ldots \ldots \ldots \ldots \ldots \ldots \ldots \ldots \ldots \ldots \ldots \ldots \ldots \ldots \ldots$

PREVIOUS ARCHAEOLOGY IN HEMISFAIR PARK $\ldots \ldots \ldots \ldots \ldots \ldots \ldots \ldots \ldots \ldots$

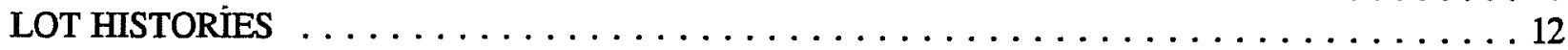

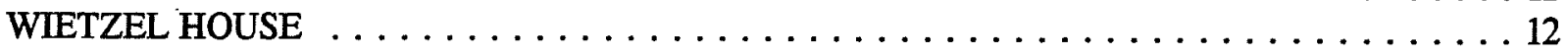

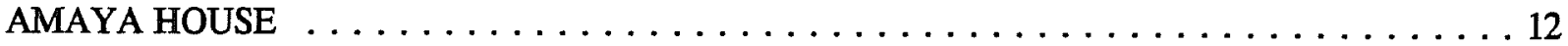

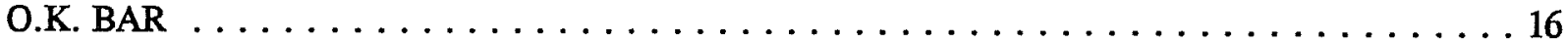

CONCLUSIONS AND RECOMMENDATIONS FOR FURTHER

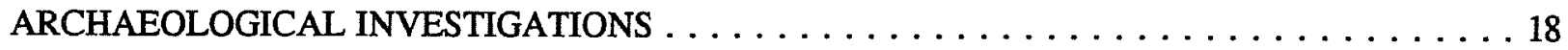

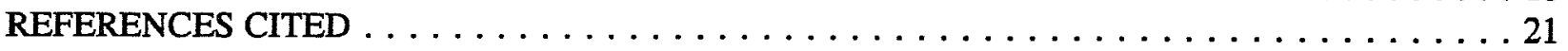




\section{FIGURES}

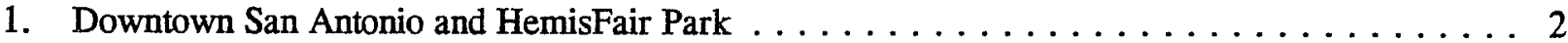

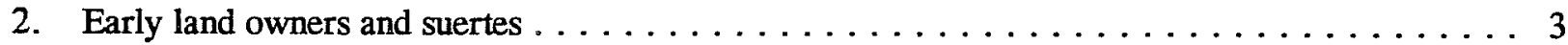

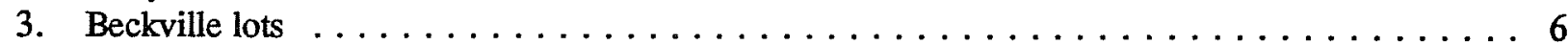

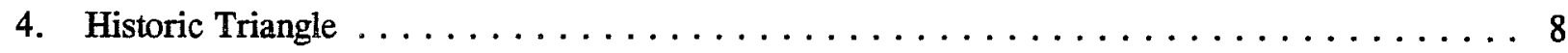

5. Current and proposed structure locations . . . . . . . . . . . . . . . . 9

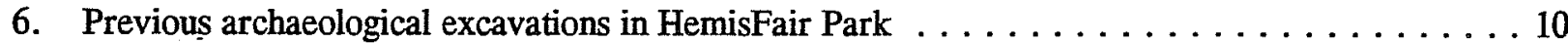

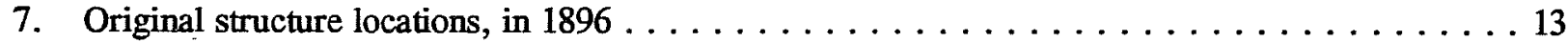

8. Detail from Bird's Eye View of the City of San Antonio, drawn by Augustus Koch in $1873 \ldots$. . . 14

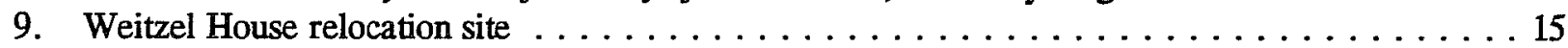

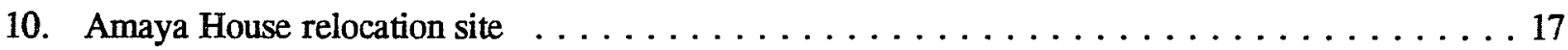

11. O.K. Bar relocation site . . . . . . . . . . . . . . . . . . . 19

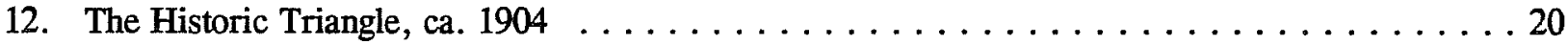




\section{ACKNOWLEDGMENTS}

We wish to express our sincere appreciation to Gary Rickoff, the county clerk, and his staff for providing access to the Bexar County archives. In addition, thanks to Jody Thomas and her staff at Stewart Title, for sharing their exceptional collection of property abstracts. We also wish to acknowledge the courtesy and assistance provided by both the staff and personnel at the Bexar County Deed Records Section, and the Texana and Genealogy section of the San Antonio Public Library.
Dr. Robert J. Hard, director of CAR and C. Britt Bousman, associate director of CAR, were the principle investigators and their guidance provided the strong foundation for this report. We would also like to thank Marcie Renner, CAR editor, for preparing this report for final publication. 


\section{INTRODUCTION}

In October 1995, the Center for Archaeological Research (CAR) of The University of Texas at San Antonio entered into a contract with the architectural firm of Kell Muñoz Wigodsky, Inc., to provide archival research and evaluation of three historic-structures in HemisFair Park and of the three lots under consideration for their relocation. This report presents the results of these investigations. Figure 1 illustrates the location of the project and the existing structures.

\section{AREA HISTORY}

The land that now comprises HemisFair Park was once part of the agricultural fields of the Mission San Antonio de Valero (the Alamo). Established on the east bank of the San Antonio River shortly after the founding of the settlement of San Fernando de Bexar on May 1, 1718, the mission was moved to its present location in 1724. By 1727 the acequia, or irrigation ditch, for the fields had been completed from an origin below the headwater of the San Antonio River, in presentday Brackenridge Park, to within a league of the mission (de Paredes 1727). The acequia traced a sinuous path between the river and the low hills to the east, following the contours of the land through the mission property, to return to the river near the large bend between the mission and the presidio. This first effort produced a ditch approximately 3.5 miles in length. As the mission grew, the ditch was extended to the east of the study area, and other branches were added, increasing its total length to approximately 10 miles (Figure 2).

In 1720 Mission San José y San Miguel de Aguayo was established further down river and, in 1731, missions Concepción, San Juan, and Espada were added to the chain. These missions were connected by the Camino de Misiones or Mission Road, which is represented by South Alamo Street immediately to the west of the study area. The street that crossed the river and led to the villa of San Fernando was just below the Plaza of Valero, and on the east side of the river it was double wide and lined with large cottonwood trees; a pleasant boulevard, it bore the name Alameda (now Commerce Street), named for the trees but also meaning a shaded walk. A short distance below the Alameda a road (later named Goliad Street) branched from Mission Road toward the settlement of La Bahia or Goliad. This intersection is now at the entrance to HemisFair Park.

The project area, referred as the Labor de Abajo or lower labor, was unpopulated and used as farmlands and pasturage during most of the eighteenth century. The area under investigation was situated to the west of two branches of the acequia created by a branching of the Acequia Madre, or Mother Ditch, above the church near the present intersection of $\mathrm{McCullough}$ and Avenue E. The eastern branch progressed to a point just beyond Interstate Highway 37 South, and the western branch passed through the present grounds of the Alamo. The two branches then rejoined within HemisFair Park on Goliad Street, near the Plaza of Mexico building, to form a single ditch that returned to the river near the bridge on South Alamo Street (see Figure 2). The study area would have been irrigated by an additional ditch from the western channel that began near present-day Bowie and Market streets and roughly paralleled the interstate toward the south, then drained into the Pajalache, or Mission Concepción ditch, below Brackenridge High School.

As the mission Indian population began to decline in the 1770 s, a settlement of families began to farm to the west of the project area; they were called agregados, or squatters, and many married Indians of the mission. This settlement became known as La Villita, or the little village (see Figure 2), and later became an important part of the villa of San Fernando (Habig 1977:73).

In 1790 the College of Zacatecas sent Fray Manuel Silva, commissary and prefect of missions, to evaluate the effectiveness of their efforts among the Indians. He recommended that San Antonio de Valero be secularized, and that the other four missions be reduced to only two. On January 9, 1793, the viceroy issued a decree implementing the recommendations. On February 23, Governor 


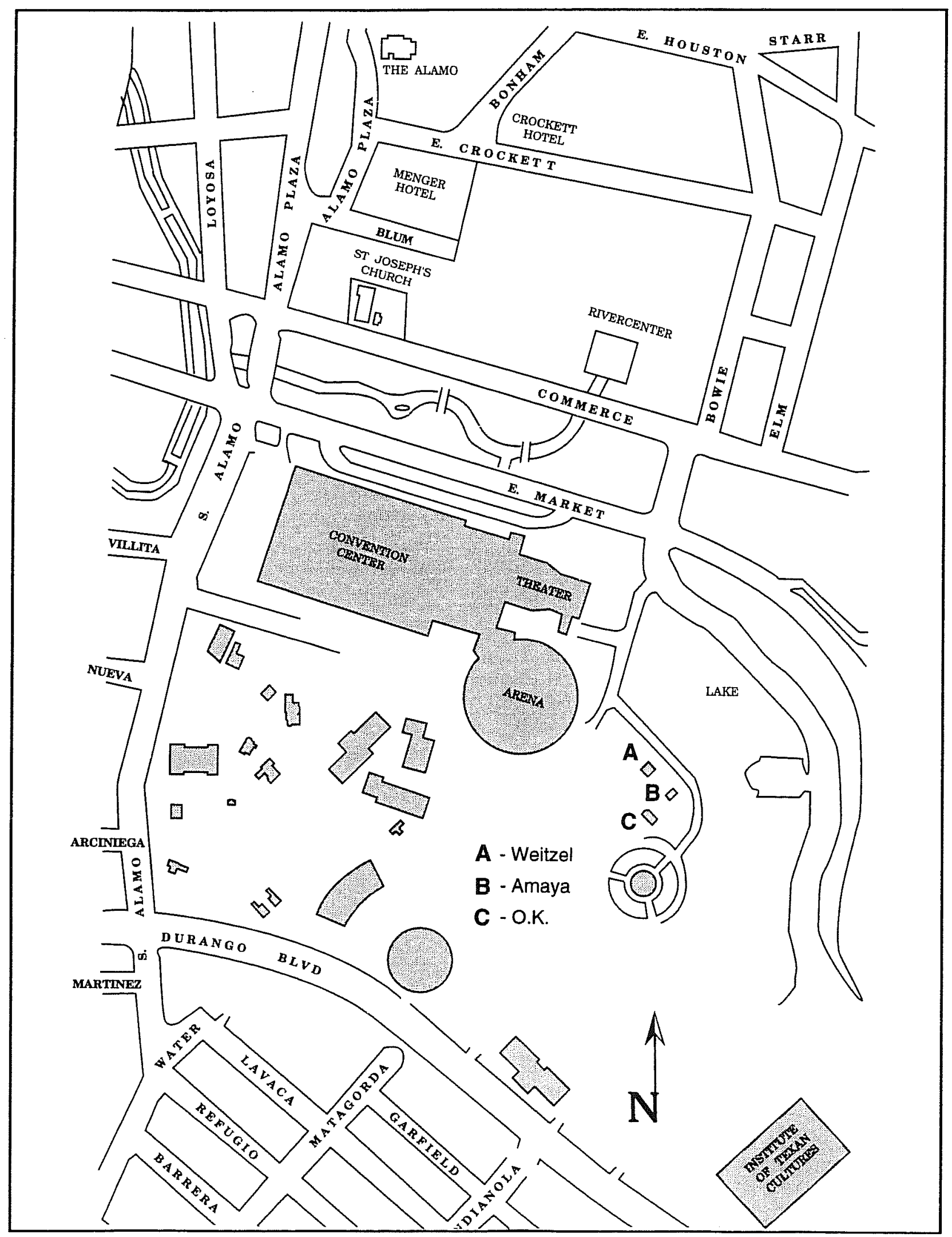

Figure 1. Downtown San Antonio and HemisFair Park. Shaded areas represent standing structures in HemisFair Park. 


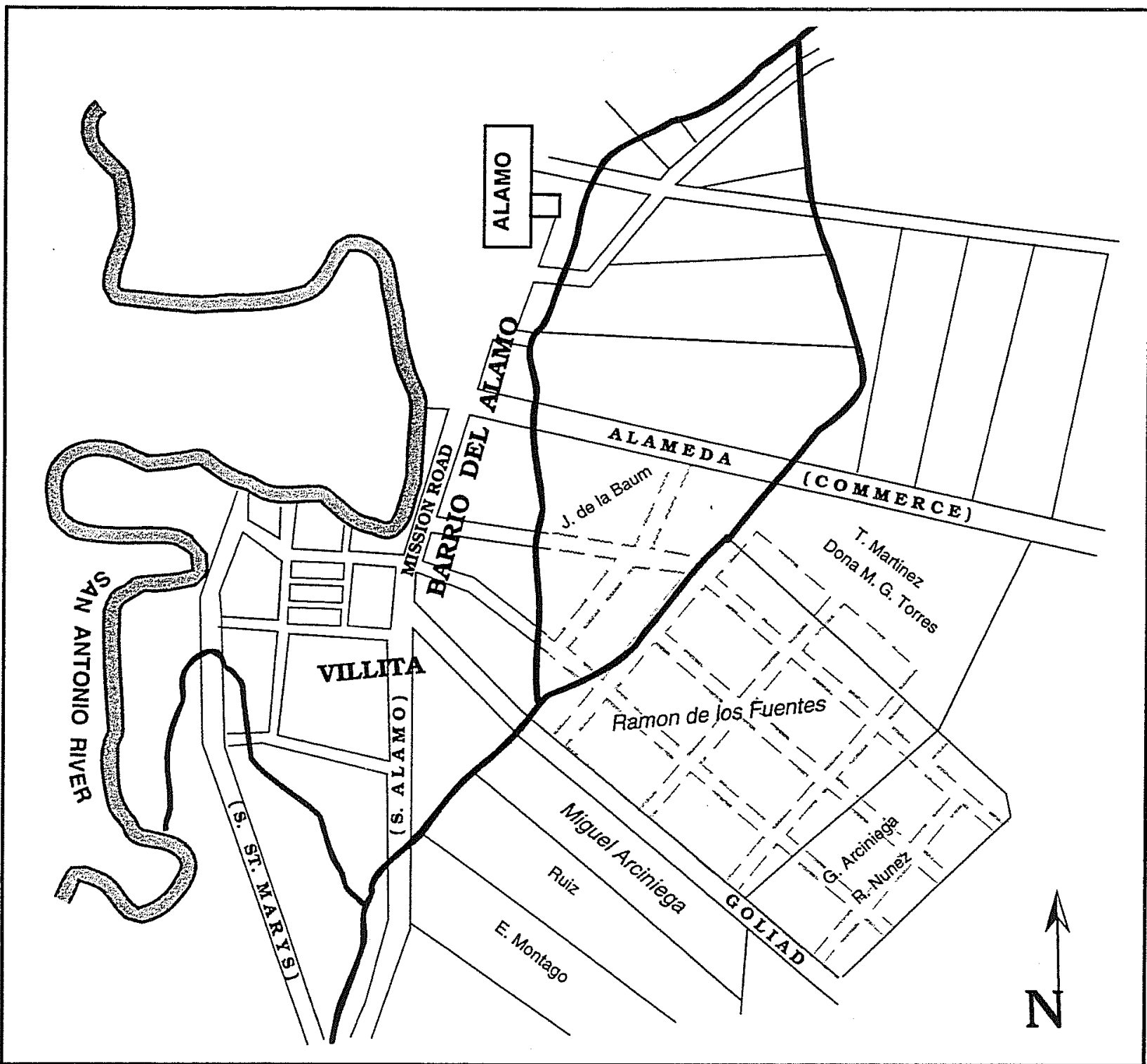

Figure 2. Early land owners and suertes. Adapted from a map by Rhulman, ca. 1913. Original on file at the Texas Historical Commission, Austin, Texas.

Manuel Muñoz published a proclamation placing the decree into effect. On April 12, the farmlands of Mission Valero were surveyed and plots given to 14 heads of families and unmarried adults of the mission. For their efforts the surveyor and his assistant, Pedro Huizar and Vincente Amador, were awarded similar tracts (Habig 1968:66-67). In October the displaced families from the East Texas missions, the Adaesanos, were granted the additional lands to the east, the Labors de Afuera, the outer farm. The remaining lands were distributed to other residents of the villa (Bexar
County Archives [BCA], Spanish Archives, Volume 3:306-315, Office of the County Clerk, Bexar County Courthouse, San Antonio, Texas; 1995:86).

Due to the courses of the acequias, the tracts of land were irregular in size. To prevent conflicts, the plots were distributed by drawing numbers and were therefore called suertes (luck) (see Figure 2). The suerte comprising the larger portion of the study area-which was one of the larger tracts, containing some 30 acres-was awarded to Ramon 
de la Fuentes (Bexar County Deed Records [BCDR], Office of the County Clerk, Bexar County Courthouse, San Antonio, Texas; Volume N1:226, G1:446). Ramon de la Fuentes was born in Saltillo, Mexico, in 1755. He came to San Antonio with his father, Toribio, in 1775, and soon married María Guadalupe Flores de Valdés (Chabot 1937:60, 70).

The Ramon Fuentes suerte was transferred to Jose Antonio de la Garza on November 3, 1808 (BCDR G1:240). Garza, youngest son of Leonardo de la Garza, was born in San Antonio on May 20, 1776 (Chabot 1937:78). There is no evidence that he made any improvements to the property. On December 20,1816, he sold the tract to Felipe Enrique Neri, Baron de Bastrop. Neri, a native of Holland, fled Europe during the French Revolution. He first settled in Louisiana, where the Spanish governor Carondelet awarded him a grant of land. Neri founded the towns of Bastrop and Mer Rouge in Louisiana, but in 1800 when the territory was acquired by Napoleon, he emigrated to Texas to remain under the Spanish crown. Neri is probably best known for his intervention with the governor of Texas on behalf of his old friend from the Louisiana Territory, Moses Austin (Stephen F. Austin's father). Austin had arrived in San Antonio to seek an interview requesting permission to introduce colonists from the United States but had been received coolly. With the support of the Baron, Austin was awarded his empresario grant, but died before he was able to introduce his colonists. His son, Stephen Fuller Austin, acquired the grant and introduced the first 300 colonists into Texas (Fehrenbach 1983:135-140). Neri later became the land commissioner for Stephen F. Austin.

The settlement of La Villita remained under the authority of the community that had developed from the old mission, but in 1809 the settlements east of the river were joined with the villa. This caused a flurry of activity in lands sales around the Alamo and La Villita (Labadie 1986:15). In 1811 a tract south of the settlement was granted to Miguel Arceniega (BCA, Land Grants and Sales:40). Miguel Arceniega, married to Alejandra Losoya, was the eldest son of Gregorio Arceniega, a soldier of the Compañia Volante de San Carlos de Parras de Alamo that had arrived in 1801 to garrison the abandoned mission of Valero. (It was from this military unit that the mission received its familiar nickname, the Alamo.) In 1827 Miguel Arceniega was appointed by the Mexican government to survey a new town for the Austin Colony. In 1832 he helped found the town of Bastrop (Chabot 1937:234), named in honor of Neri. Miguel also acquired the property east of Mission Road below Goliad Road and extending to the acequia (BCDR C2:287).

The year 1811 saw Mexico's first efforts to gain independence from Spain. Father Miguel Hidalgo's cry for revolution in Mexico immediately spread to San Antonio with Juan Bautista Casas's declaration of an independent government in support of Hidalgo. Although quickly overthrown, the territory was left in turmoil and, in March 1813, the city was captured by the forces of the Republican Army of the North of GutierrezMcGee. This brought swift and bloody retaliation by Spain under General Joaquin de Arredondo, leaving the country in shambles for the next decade (Cox 1992:6).

One solution to correct this decimation on the frontier was the proposal to open the territory to outside colonization. Austin was only the first of several impresarios bringing a steady influx of settlers. While this achieved the desired habitation of the frontier, it created a colony largely consisting of Anglos with little loyalty or dedication to the Mexican state. Soon this led to conflict between the colonists and the new Mexican Republic. In December of 1835, an army formed by the "Texians" captured the city of San Antonio and began an escalation of military activity in Texas. On February 23, 1836, General Santa Anna and his troops arrived to lay siege to a group of Anglos who had taken refuge within the walls of the old mission. Although the current project area was situated near the site of that now-famous battle, its open fields did not figure directly in the action.

Following Santa Anna's defeat in the rout at San Jacinto, the territory emerged as the Republic of 
Texas (Webb 1952 I:22-23, II:554). This was followed over the next three decades by a period of steady growth for San Antonio, resulting in a population increase of 136 percent (United States Department of the Interior, Office of the Census 1850,1860 ). In most of Texas this immigration growth was from the South, but in San Antonio the growth was predominately from Europe. By 1850 Europeans, mostly German, outnumbered both Mexicans and Anglos (Fehrenbach 1983:285). This unprecedented population increase stimulated land speculations, resulting in the purchase of large blocks of land platted into town lots for resale. The anticipated transfer of the lots often did not occur for many years (Cox 1992:9).

After the death of the Baron de Bastrop, his heirs sold the Fuentes suerte to Philip Dimmitt on October 12, 1829 (BCDR C2:121). Dimmitt, born in Kentucky in 1801 , came to Texas in 1822 as a trader. He married María Luisa Lazo in 1828 and became a successful merchant. He joined the "Texians" in the siege of Bexar and was appointed by Austin to command the garrison at Goliad. His force at the old mission issued the Goliad declaration of independence from Mexico on December 20,1835, preceding the official action of the congressional congress by almost four months. Dimmitt died defending the garrison during the conflict (Hardin 1994: 41, 46, 105-106; Walraven 1993:47). His heirs sold the Fuentes suerte to Volney E. Howard at public auction on June 7, 1845, for $\$ 100$ (BCDR C2:121). On April 30,1848 , Howard transferred the entire tract to Matt K. Evans. Evans then sold the parcel to Joseph R. Beck on October 16 of the same year (BCDR N1:226, G1:445-446). Beck had the tract surveyed and divided into town lots that became known as Beck's Division or Beckville (Figure 3).

The portion of the Arceniega grants between Mission Road (South Alamo Street) and the acequia was seized by the sheriff, in 1844 , for nompayment of taxes. As allowed by law, both then and now, the property was offered for sale by public auction announced from the steps of the courthouse on the first Tuesday of the month. The tract, now New City Block (NCB) 127, was purchased by John Riddle as the highest bidder on November 9, 1844 (BCDR C2:287).

The project area was slow to grow during the early years, but by the late 1870 s and 1880 s had developed into a fashionable neighborhood. Many stately homes were constructed along Goliad Street, many of which were owned by German merchants such as the Halff brothers, Solomon and Mayer. Other merchants built impressive homes along Water Street, so named because of the acequia it paralleled. During these years segregation was not practiced, and the neighborhood was home to all races. It also boasted churches of most major religious sects: Catholic, Protestant, and Jewish. Yet, over the years, the neighborhood gradually declined, and the homes became rentals as the owners died or moved away. The homes along South Alamo Street were replaced or converted to commercial uses (Fox and Cox 1990:1).

In 1964 the city of San Antonio began preparation for HemisFair 1968, an international exposition to be held in the downtown area east of South Alamo Street, with Goliad Street as the main thoroughfare of the complex. At this time attention became focused upon the historic homes within the area that were to be affected. Several civic groups, predominately the San Antonio Conservation Society, rallied to save many of these structures by adapting them for use during the fair. Among these were the Eager home (434 South Alamo), the Perieda home (502 South Alamo), The Halff homes (Goliad Street), and the Samuel Smith home (corner of Goliad and Water streets).

Along with others, the three structures under consideration in this study-the Wietzel house, the Amaya house, and the O.K. Bar-were preserved as a group at the intersection of the street where they had originally been constructed (Cox and Fox 1983:2, 13). This report addresses the histories of each of these structures and the sites under consideration for their relocation. 


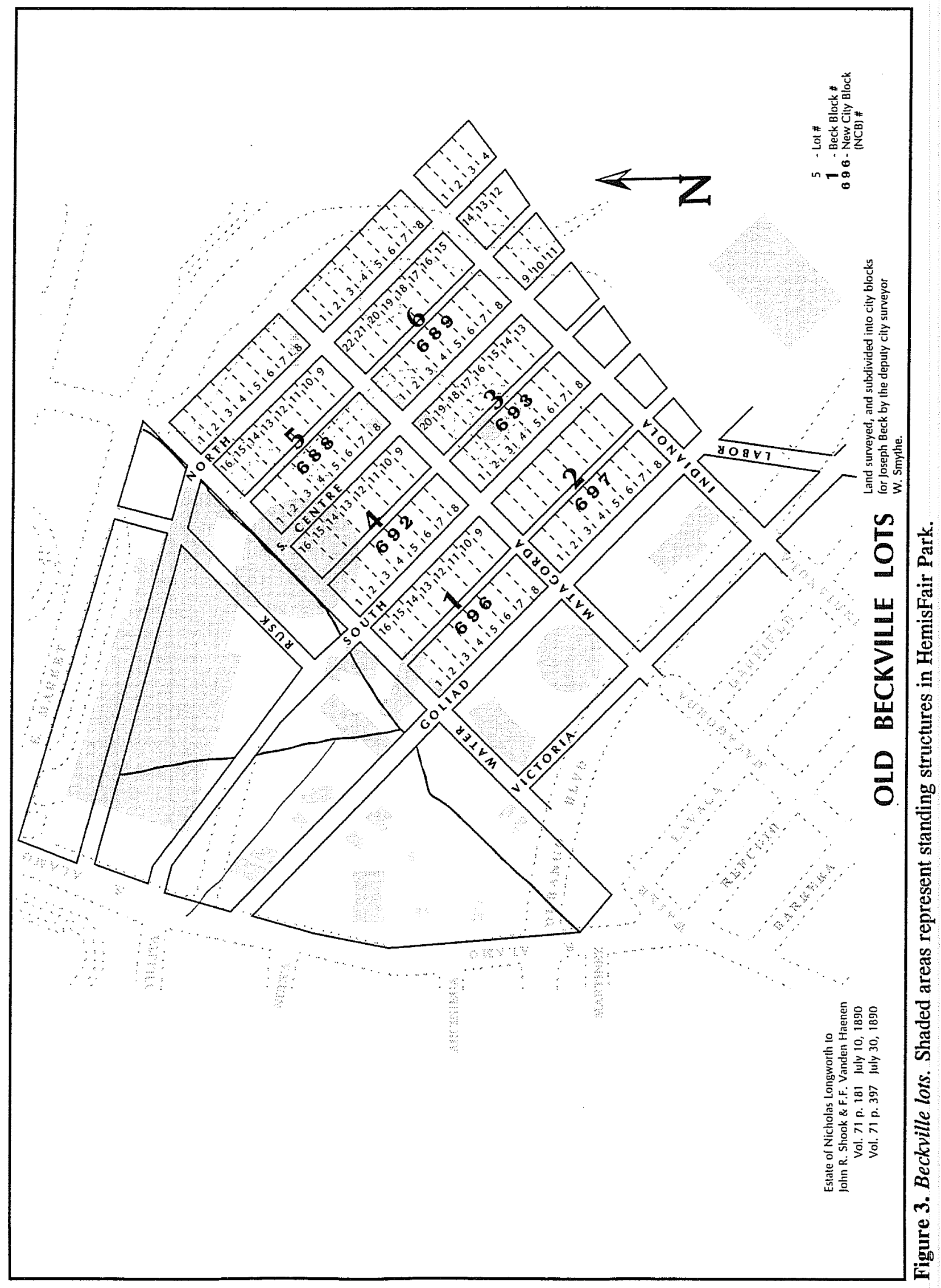




\section{PREVIOUS ARCHAEOLOGY IN HEMISFAIR PARK}

The international exposition, HemisFair 1968, took place in an older residential section of the city. Construction of HemisFair began in 1966 amid the dilemma of how to move San Antonio into the future yet still preserve an important segment of the city's rich historic past. The grounds of HemisFair Park contained several historically and archaeologically significant structures.

At the time few laws, regulations, or guidelines concerning historic preservation existed or were enforced. Accordingly, a full assessment of properties within the area was not conducted until 1983 (Cox and Fox 1983). By this time many structures had been demolished or moved from their original locations. Before construction of HemisFair a compromise was reached: a group of buildings would be selected for preservation; renovated and integrated as part of the exposition, some of these structures are still in use today. Most of these buildings are in the southwest corner of HemisFair Park in an area known as the Historic Triangle (Figure 4). This area is roughly bounded on the north by old Goliad Street, the east by old Water Street, the west by South Alamo Street, and the south by Durango Boulevard. The original route of old Goliad Street was retained as a promenade through the fair grounds and some preserved structures line this street. Included in the original group of preserved buildings are several structures outside the Historic Triangle, among them the three structures of this project.

The Wietzel House, Amaya House, and O.K. Bar are presently located in the northern sector of HemisFair Park (Figure 5). The planned construction project will move the Wietzel and Amaya houses to Goliad Street, and move the O.K. Bar to a parcel near South Alamo Street within the Historic Triangle (see Figure 5).

Although HemisFair Park covers a large and historically significant area, only a few archaeological investigations have occurred in the park (Cox 1992; Cox and Fox 1983; Fox and Cox 1990), and thus far these have mostly been restricted to the Historic Triangle (Figure 6). The excavations have revealed sections of the Acequia Madre and one historic structure, the Huebaum House. No archaeological investigations have occurred at the three historic structures or the three lots selected for their eventual locations.

The first archaeological investigation on the grounds of HemisFair Park occurred during construction for the exposition in 1966 when a section of the Acequia Madre (41BX8) was encountered. The route of the acequia was easily traced by observing the ditch's stone walls. About $50 \mathrm{ft}$ of the acequia were visible at the surface within the Historic Triangle. Under the direction of Mardith Schuetz, curator of anthropology at the Witte Museum, volunteers excavated a short segment of the ditch (see Figure 6). The primary purpose of the excavation was to clean out part of the acequia so that it could be used as a water feature in the exposition's Spanish Pavilion (Fox and Cox 1990:3). The Schuetz investigations revealed that the bottom of the acequia was $5.2 \mathrm{ft}$ below the surface and the excavated section was $6.3 \mathrm{ft}$ wide. Walls of the acequia were lined with quarried limestone blocks varying in thickness from 10 to 14 inches, with lengths from 11 to 41 inches. A few late-nineteenth-century household items were recovered (Schuetz 1970:7-13). After the excavation, a circulating water system was installed. In addition, the southern part of the Spanish Pavilion and other structures were built over the acequia before its location could be accurately mapped. This effectively hid a large portion of the acequia and prompted subsequent archaeological investigations.

In December 1983, CAR began test excavations at HemisFair Park. The goal was to locate and document the condition of the Acequia Madre (41BX8). The project consisted of backhoe trenches and hand excavations. During this phase items similar to those excavated by Schuetz in 1966 were found, but the acequia was not.

The project resumed in February 1984. Trench 1 was opened near the intersection of South Alamo Street and Durango Boulevard (see Figure 6), but did not expose the acequia. The acequia was finally 


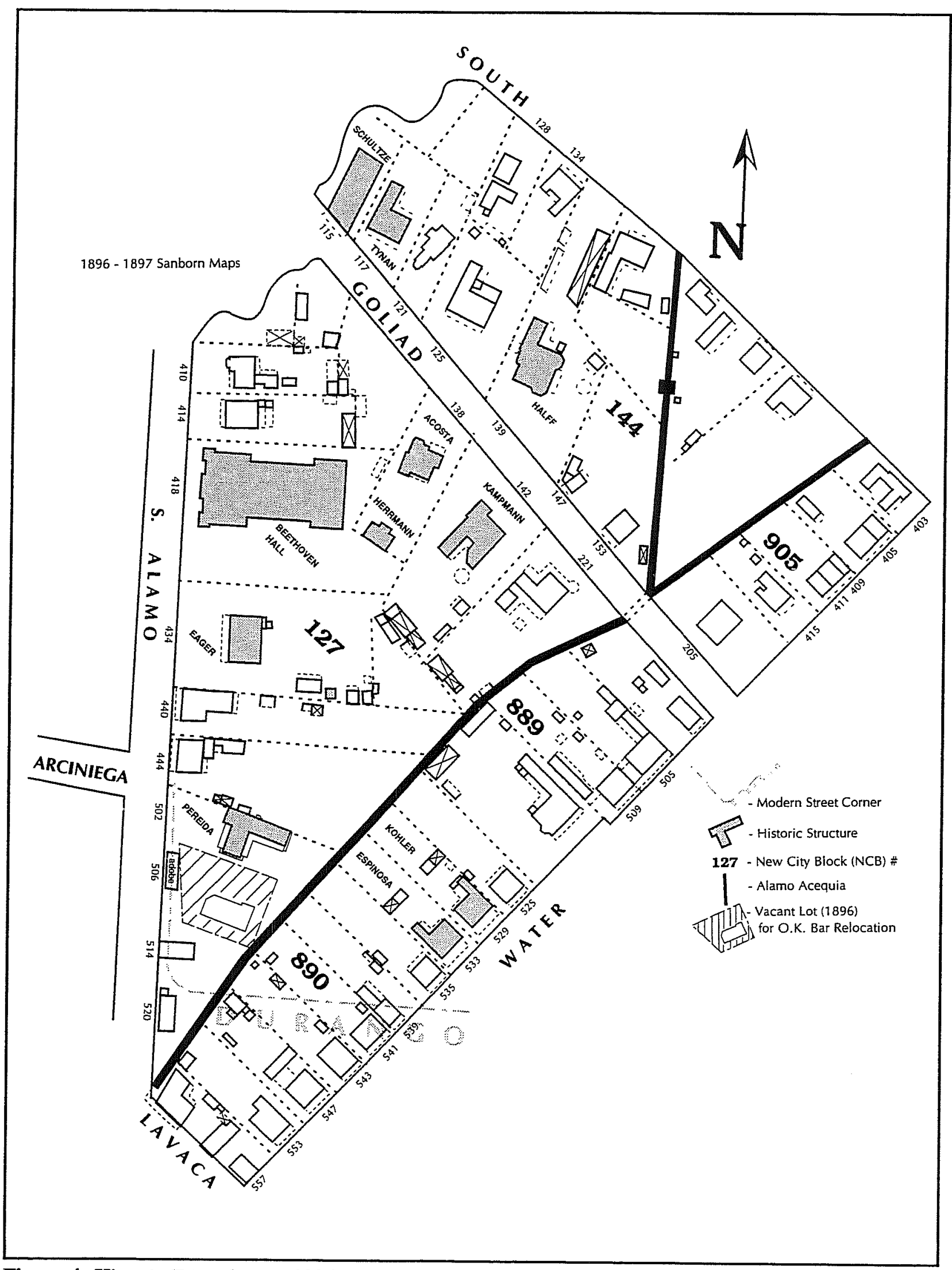

Figure 4. Historic Triangle, ca. 1896. 


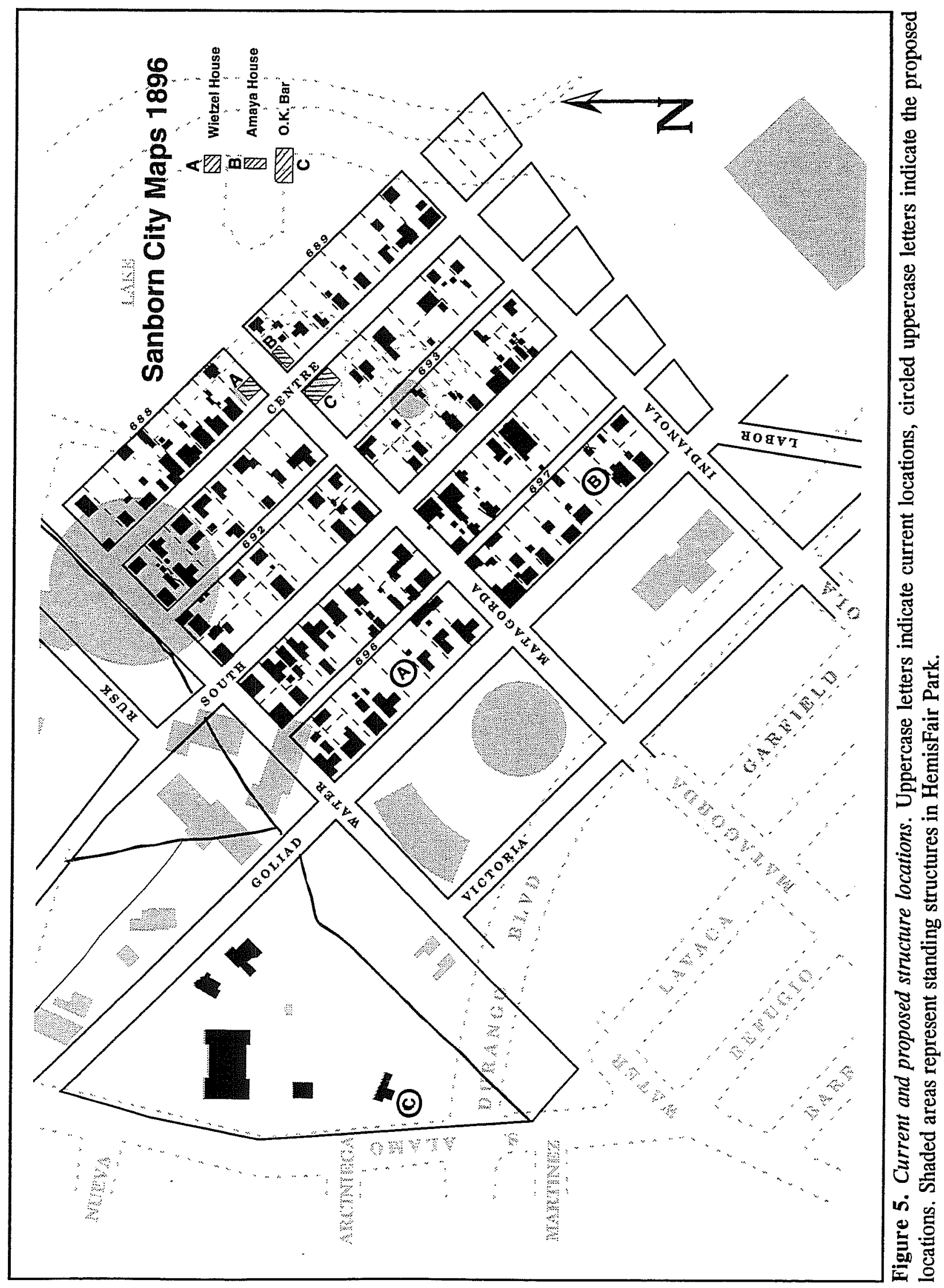




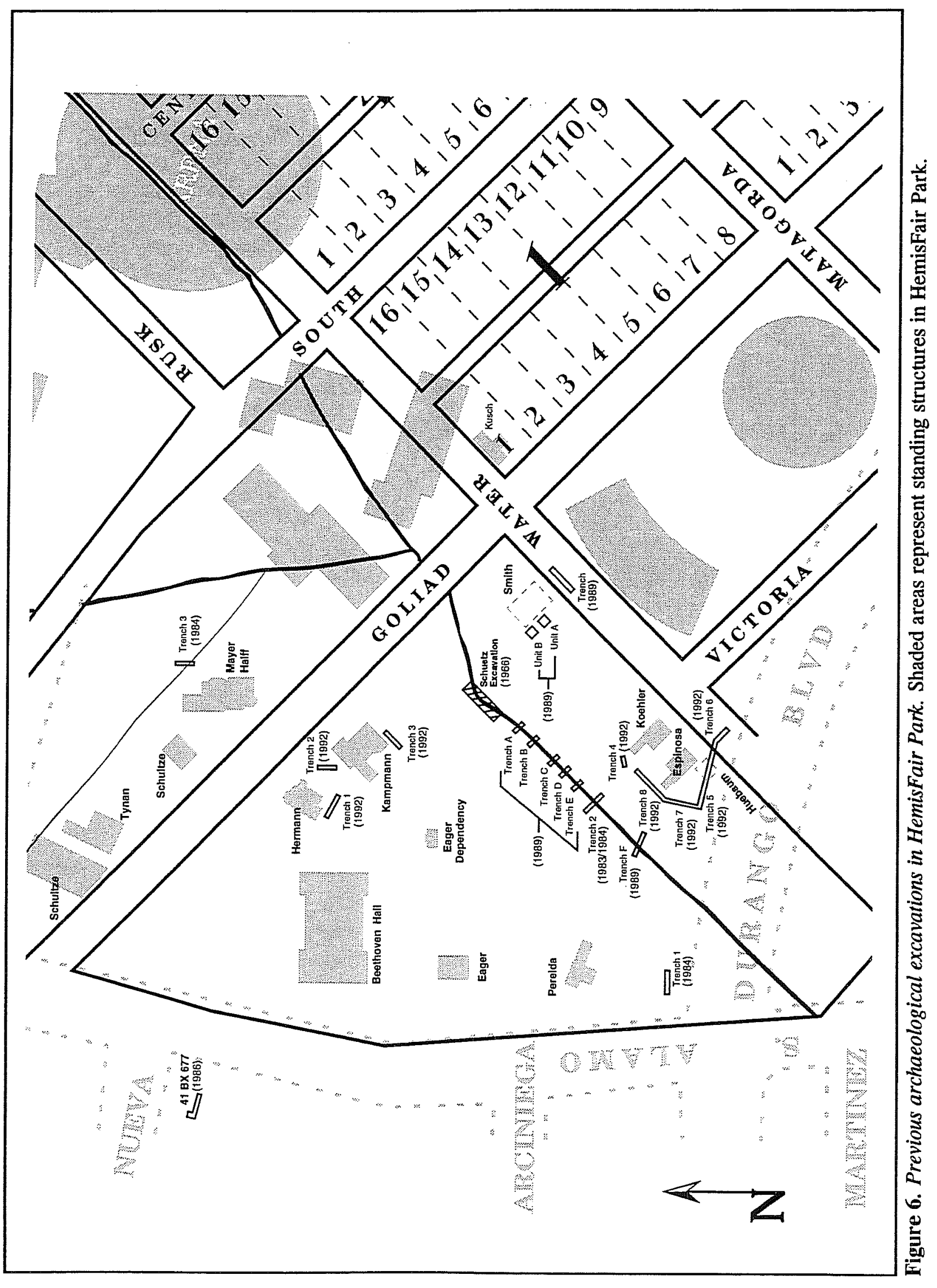


encountered at the eastern end of Trench 2 (see Figure 6), which was begun in December and expanded in February. The crew found evidence of the remaining limestone wall and a deposit of artifacts at five feet below the surface. Trench 3 was on the north side of Goliad Street, east of the Mayer Halff House (see Figure 6). This trench cut across the route of a lateral ditch that ran northwest off the main acequia. The ditch was merely an unlined, shallow trench dug into the soil. The results of the project showed that the Acequia Madre was still in relatively good condition south of the Transportation Museum. Investigations also showed that the acequia does not run in a straight line from the Schuetz excavation to the intersection of South Alamo and Durango as previously expected. The exact route of the acequia south of Trench 2 remained open for investigation (Fox 1985).

In January 1989, CAR began another phase in the continued efforts to find and document the condition of the acequia. Given the previous difficulties locating the acequia, archaeologists decided to continue from the known portion at the north end, located by Schuetz, with regularly placed trenches. The channel would then be found before proceeding to the next trench. Each trench had a width of four feet. The backhoe removed the upper layers of HemisFair fill, until the first signs of the acequia walls appeared. Excavation by hand was conducted below that point and screening was done through $1 / 4$-inch mesh. In the process, six test trenches were open (see Figure 6; Trenches A-F). Recovered data showed that in most locations the east wall was in relatively good condition. In comparison, the west wall had been removed. Ceramics included earthenwares (unglazed, burnished, lead-glazed, tin-glazed, whiteware, and yellow-ware), stoneware, and porcelain. A few eighteenth-century sherds, similar to those from the Schuetz excavation, were recovered from Trench A. Trench A also produced the largest variety and highest number of sherds.

The project showed that the acequia was still present and that the stone removal took place after trash deposits accumulated. The trash fill in the acequia was deposited in a single operation after the ditch no longer carried water. After the archaeological project, stonemasons raised the acequia walls and poured a concrete bottom. This provided the shallow channel that now carries recirculating water through the northern half of the area (Fox and Cox 1990).

Later in 1989 the Texas Antiquities Committee recommended further testing before a planned landscape project. Two units and a backhoe trench were opened near the Smith House (see Figure 6) near the corner of Goliad and Water streets. Undecorated ceramics and cut nails that appear to be post- 1850 were found; this date agrees with the period of the Smith house construction (Fox and Cox 1990).

In July 1992, I. Waynne Cox conducted archaeological monitoring during utilities installation at HemisFair Park. Three trenches were monitored near the Hermann and Kampmann houses on old Goliad Street. An additional five trenches were monitored near the Koehler and Espinosa houses on old Water Street (see Figure 6). Trench 5 revealed the foundation of the Huebaum house immediately south of the Espinosa house. This site was subsequently designated $41 \mathrm{BX} 982$ and represented the only significant cultural remains discovered during the project (Cox 1992).

Although it is not located within the project area, La Villita Earthworks (41BX677) represents a significant archaeological site just beyond the confines of the park (see Figure 6, Nueva Street). Archaeologists retrieved material evidence associated with General Santa Anna's siege works. Additionally, trench fill gives a comprehensive look at San Antonio in the mid-1800s (Labadie 1986:i). HemisFair Park's proximity to 41BX677, the San Antonio River, and the Alamo acequias, greatly increases the area's potential for other significant archaeological discoveries. 


\section{LOT HISTORIES}

Individual lot histories have been collected for the three historic structures and the three lots selected for relocation. These are the Wietzel House, the Amaya House, and the O.K. Bar, as well as NCB 696 Lot 5, NCB 697 Lot 6, and NCB 127 Lot 14 (see Figure 5):

\section{WIETZEL HOUSE}

135 Wyoming (Centre) Street (HemisFair \#587; NCB 688; Lot 8; Beck Block 5)

One of the earliest recorded transactions in the records involving this parcel occurred on July 9 , 1859. Joseph Beck sold Lots 5-8 to Rochius Wozgsey for $\$ 308$ (BCDR R1:459). Located on the north side of Centre Street (later Wyoming) between Water and Second (later Matagorda) streets, these four tracks were all eventually acquired by members of the Wietzel family (see Figure 5). HemisFair Park's Wietzel House still stands on Lot 8 at the corner of old Wyoming and Matagorda Streets (Figure 7).

Jacob Wietzel acquired Lots 7 and 8 from Rochius and Maria Wozgsey in 1865 for $\$ 100$ (BCDR $\mathrm{T} 1: 388$ ). Given the relatively small amount of money paid for the two lots, the tracts may have been undeveloped at the time. However, Augustus Koch's 1873 drawing, Bird's Eye View of the City of San Antonio, clearly shows a house on the lot (Figure 8). The house is also shown on the 1896 Sanborn Insurance Map (see Figure 7). Because Jacob Weitzel died intestate in 1925, Charles A. Fischer acted as the administrator for the Wietzel estate and guardian for Wietzel's minor children. To settle the estate, Fischer sold several properties, including the four lots on Wyoming Street. Mary and George F. Eckenroth and other members of the Wietzel family paid $\$ 3,500$ for the parcels (BCDR 834:616). Mary Eckenroth was the daughter of Mary Wietzel, and a later notation states that the property was part of her inheritance (BCDR 1337:455).

By 1933 a resubdivision of the lots had occurred and the four parcels became part of Lot $D$. That same year Mary Eckenroth sold the Wyoming Street lots for $\$ 10$ and "other good and valuable considerations" to Theresa Rose Hochwater (BCDR 1337:455). Mary had a sister named Theresa; this was probably she. In 1944 the same lots are again transferred and mentioned as part of a resubdivision, now as Lot $C$. This time Caroline Wietzel, in a deed of gift, gave the four lots to her widowed sister Elizabeth Gros (BCDR 2043-85).

\section{Wietzel House Relocation Site 319 Goliad Street (NCB 696; Lot 5; Beck Block 1)}

The new site for the Wietzel house is at 319 Goliad Street (see Figure 5). Lot 5 of NCB 696 was one of 16 lots sold by Joseph Beck to Nicholas Longworth in August 1855. Mr. Longworth paid $\$ 1,725$ for the parcels on Goliad, Centre, North, and South streets (BCDR N1:226).

Koch's 1873 bird's-eye-view map shows that Lot 5 was vacant at that time (see Figure 8). In June 1890, Larry Anderson acted as executor for the deceased Longworth and sold the lot for $\$ 1,200$ to Morris Friedman (BCDR 64:375). Although there were houses all along the block, the 1896 Sanborn Map indicates this lot was still empty (Figure 9). A few days earlier Mr. Anderson had also sold Lot 4 for a similar price to Mary McAllister (BCDR 64:339). The McAllister name appears in 1895, this time at Lot 5. Mrs. Ida Caroline McAllister purchased the parcel for $\$ 1,500$ from Morris and Sallie Friedman (BCDR 154:52). A large house on this lot is shown on the 1904 Sanborn Map. City Directories (CD) indicate that S. Joe McAllister resided at 319 Goliad from 1896 through 1919 (CD $1896,1900,1904,1905,1907,1913,1919)$. The city began improvements along Goliad Street in 1915, grading and paving its entire length from Alamo Street to Peach Street (BCDR 474:297).

\section{AMAYA HOUSE}

201 Wyoming (Centre) Street

(HemisFair \#403; NCB 689; Lot 1; Beck Block 6)

The Amaya House is also on the north side of Wyoming at the junction of Matagorda and Wyoming streets (see Figures 6 and 7). Traveling 


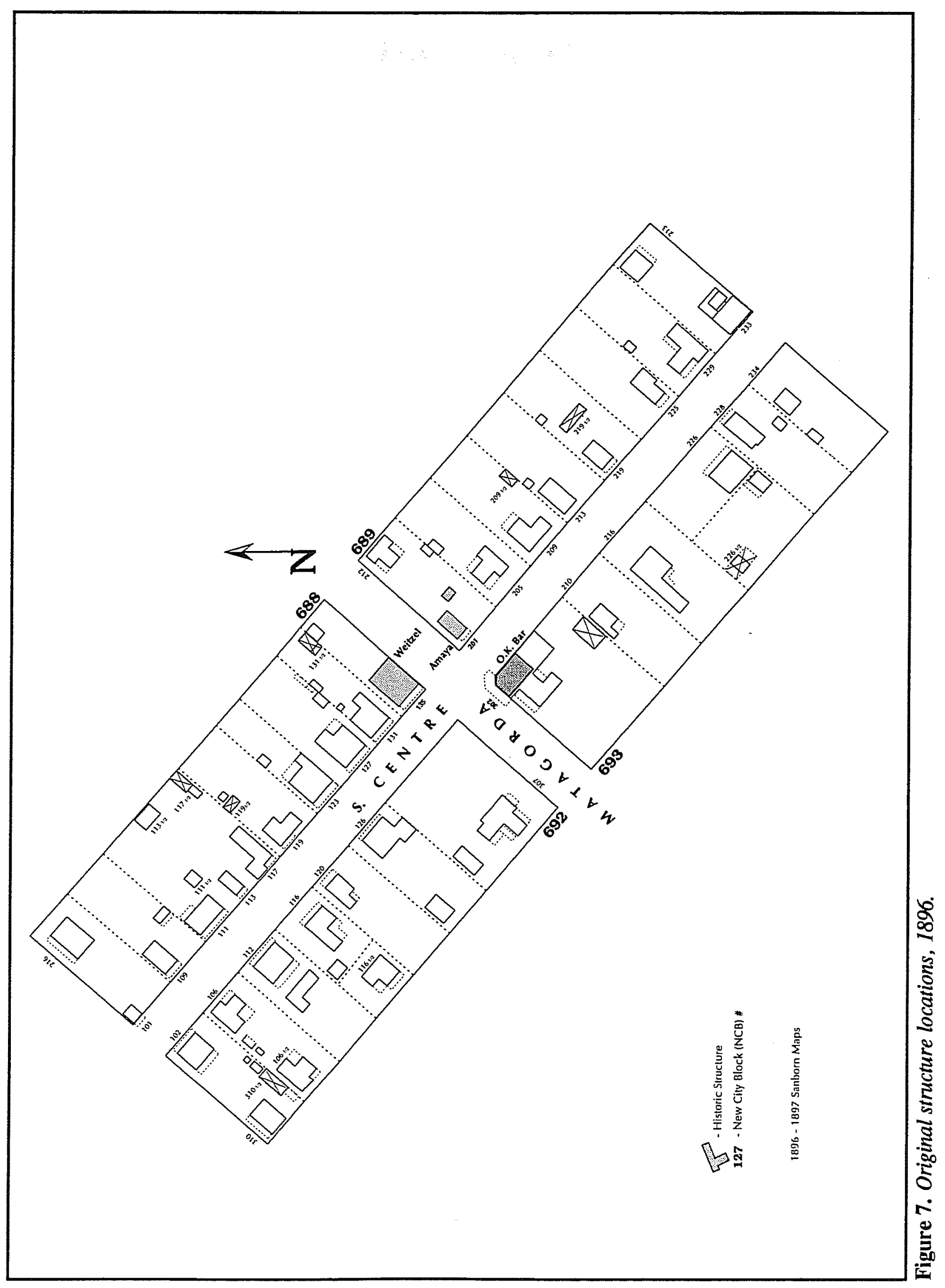




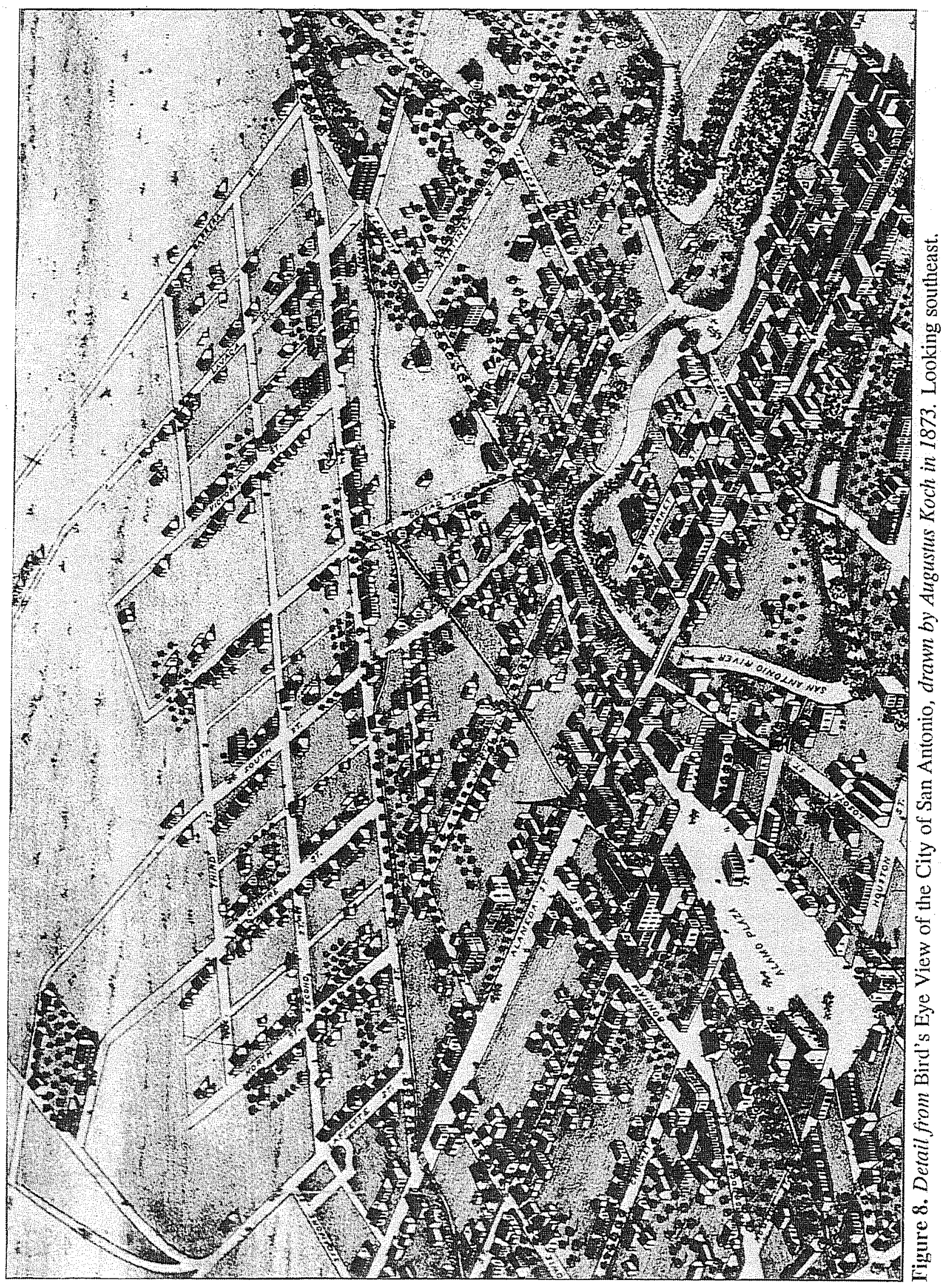




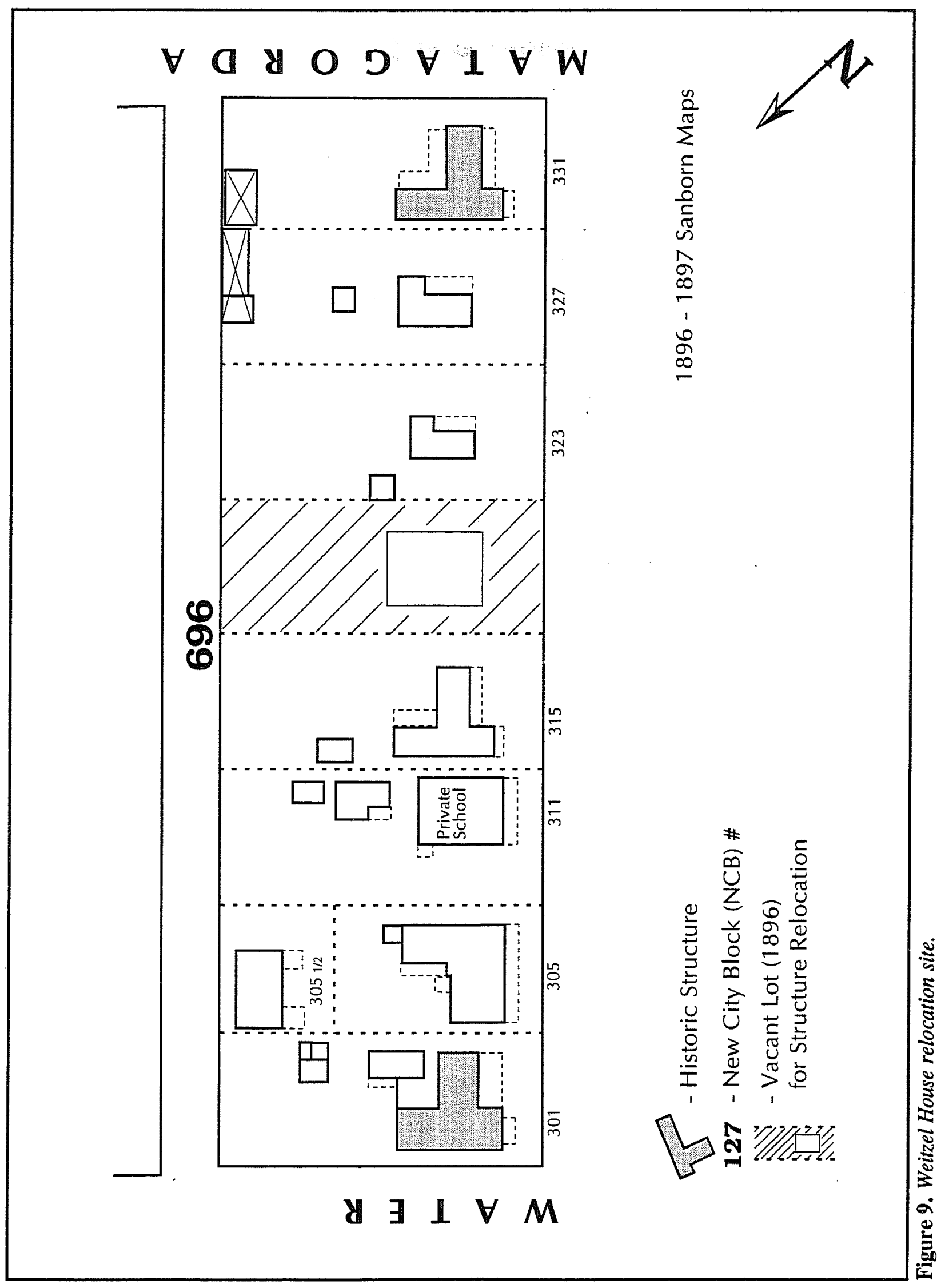


southwest from the Wietzel House, the Amaya House is just across Matagorda Street. In January 1859, Joseph Beck sold Lots 1 and 2 for $\$ 175$ to Walter C. Tynan (BCDR R2:525). Tynan quickly resold these parcels in August of the same year for $\$ 225$ to William Cuff (BCDR R1:553). In 1865 this area was known as Beckville, and Matagorda Street was Second Street. Carl Dobrowolsky purchased the lot on the corner of Second and Centre for $\$ 300$ (BCDR T2:5).

Koch's 1873 bird's-eye-view map (see Figure 8) and the 1896 Sanborn Map (see Figure 7) show the Amaya House. Different renters occupied the house through the years, but Charles Amaya is shown as the owner in 1951 (CD 1904, 1905, 1907, 1919, 1951).

\section{Amaya House Relocation Site 423 Goliad Street (NCB 697; Lot 6; Beck Block 2)}

In November 1856, Joseph Beck sold another group of his lots to Clarissa L. Cotton and other members of her family. The Cottons paid $\$ 325$ for three lots on Block 2 and two additional lots adjoining the block (see Figure 5). Clarissa was listed for Lot 5, but Jepha Cotton had Lot 6 (BCDR O2:236). Koch's 1873 bird's-eye-view map shows a house on Lot 6 (see Figure 8), but the 1896 Sanborn Map shows the lot vacant (Figure 10).

E. G. Huston and Clarissa L. Huston (the former Clarissa L. Cotton) signed a deed of trust in 1874 for Lots 5 and 6 (BCDR 3:49). In 1877 they met the obligations of their promissory note by paying the Lodge of Independent Order of Oddfellows of San Antonio, Texas, $\$ 500$ for the tracts (BCDR 5:332). The property subsequently changed hands through other deeds of trust. Joseph Rymankiewiez sold the lots to Minnie M. Shipp in 1883 (BCDR 31:77).

J. H. and M. M. Shipp sold the lot to Jacob Aniol for $\$ 300$ in 1884 (BCDR 32:606). Acting as the administrator for Jacob Aniol's estate, Annie C. Aniol then sold the lot in 1897 for $\$ 750$ to D. S. Taylor (BCDR 160:558). After the turn of the century, city directories show many different renters at 423 Goliad, but in 1910 D. S. and Marie Taylor released the property to Mrs. Johanna Hallmann. Mrs. Hallmann had started making payments on the lot in 1908 and by 1910 had paid the Taylors \$1,427 (BCDR 344:341). Johanna Hallmann is later shown as the owner of the lot (CD 1913, 1919).

\section{O.K. BAR}

204 Wyoming Street and 302 Matagorda Street (HemisFair 406; NCB 693; Lots 19 and 20; Beck Block 3)

The O.K. Bar lots were two of 16 lots sold by Joseph Beck to Nicholas Longworth in August 1855 (see Figure 5). Mr. Longworth paid \$1,725 for the parcels on Goliad, Centre, North, and South streets (BCDR N1:226). (This was the same transaction that included the lot for the new location of the Wietzel House.) According to Koch's 1873 bird's-eye-view map (see Figure 8), the lot on the southern corner of Second and Centre streets was vacant. The 1896 Sanborn Map shows a structure on the lot that may be the same structure that housed the O.K. Bar, and an attachment that may have been part of the building on the lot to the east (see Figure 7). By 1896, some lot boundaries had changed from their original Beckville and Longworth locations. The 1913 city directory shows the O.K. Grocery and Market at 302 Matagorda. Because the lot is on a corner, the 1919 directory lists 302 Matagorda as the O.K. Grocery and 204 Wyoming as the O.K. Bar (CD 1913, 1919).

O.K. Bar Relocation Site (NCB 127 Lot 14) 506, 508 South Alamo

The new location for the $\mathrm{O}$. K. Bar is on the lot immediately south of the R. M. Pereida House in the Historic Triangle (see Figure 5). In fact, the Pereidas once owned the land. His neighbor to the immediate south on Alamo Street, Pedro Cabrera, sold Pereida the lot in 1890 (BCDR 76:432). The 1892 Sanborn Map shows a small structure just south of the Pereida House and the 1896 Sanborn Map indicates that it is an adobe (cut caliche block) building (Figure 11). The foundation for this 


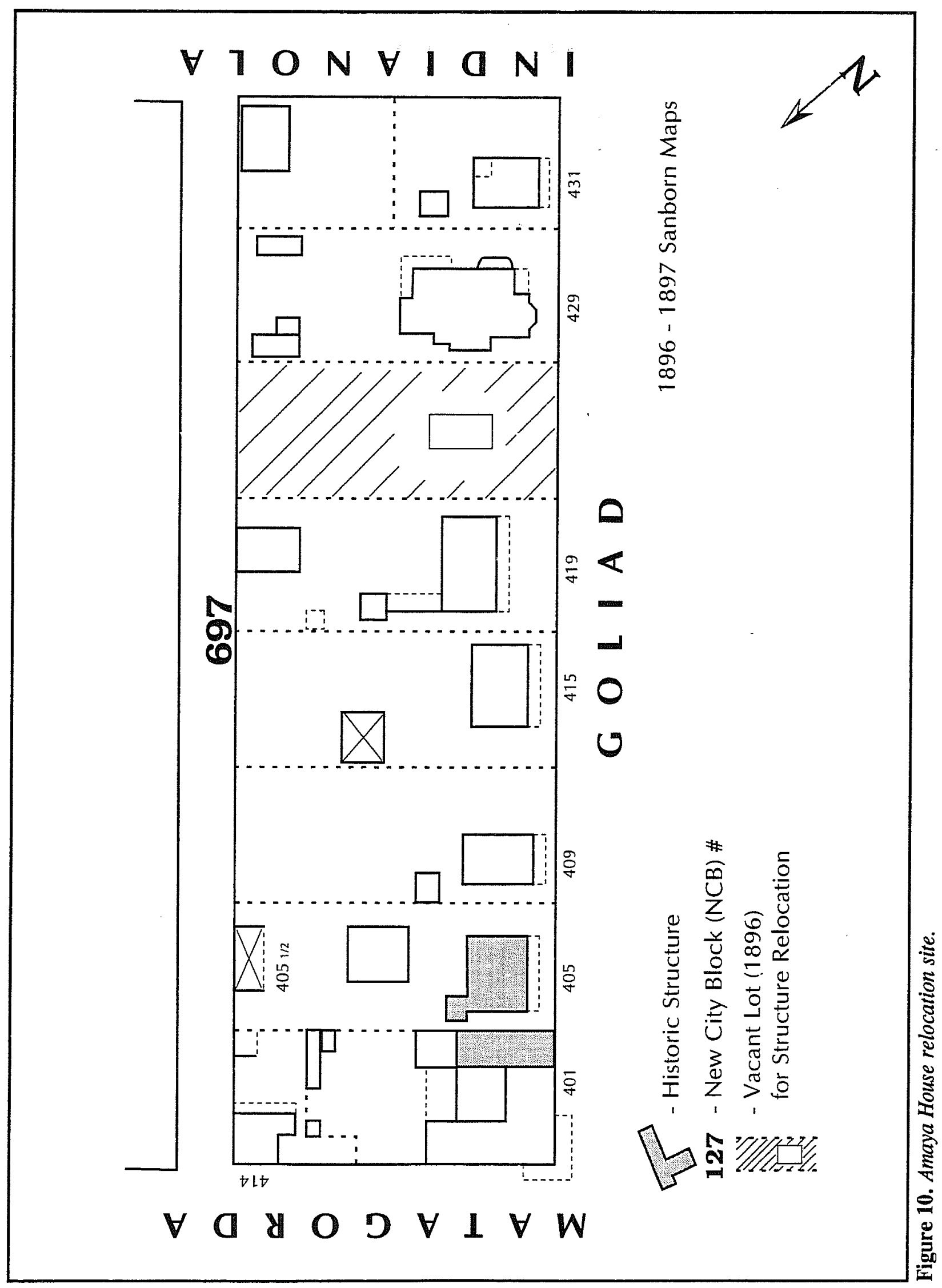


structure was most likely destroyed when South Alamo Street was widened in 1929 (BCDR 1095:114). The 1904 Sanborn Map clearly shows a large house $508 \mathrm{~S}$. Alamo Street on Lot 14, but the structure is not shown on the 1897 map (Figure 12). Therefore, the large house must have been built sometime between 1897 and 1904. Barbara Bosshardt purchased the lot from Perieda for $\$ 1,200$ in January 1904 (BCDR 226:341). City directories from 1905 and 1907 list Miss Bosshardt as the owner at $506 \mathrm{~S}$. Alamo Street; however, the lot was actually sold again in 1906. Charlotte J. Hewitt made a down payment of $\$ 1,800$ cash toward the total $\$ 4,200$ price in November 1906 (BCDR 248:527). Ownership of the property then changed hands again in 1913 when Clara J. Winlack paid Miss Bosshardt $\$ 4,500$ for the deed (BCDR 259:99). Clara Winlack subsequently turned over the property to L. F. Birdsong for $\$ 6,000$ in 1915 (BCDR 462:190). The city directory still listed the Birdsongs as the owners in 1919. By 1951 the site had become a lot for J. Gordon Cottingham's used cars (CD 1951).

\section{CONCLUSIONS AND RECOMMENDATIONS FOR FURTHER ARCHAEOLOGICAL INVESTIGATIONS}

Archival research indicates that the Wietzel and Amaya houses were the first structures to be constructed upon their present locations. Lot selling prices in 1865 and Koch's 1873 birds-eyeview map indicate that both houses were built between these dates. The O.K. Bar building is apparently the first structure on the lot and the earliest evidence for this building dates to the 1896 Sanborn Map. The O.K. Bar has a basement; but if prior structures had been present but not recorded in the archival records, then consiruction of the basement would have destroyed any traces of older buildings. The archival investigations failed to discover any specific references to the basement at the O.K. Bar. As the O.K. Bar was constructed during the late nineteenth century, this property duplicates information, in terms of time period and ethnic affiliation, collected on a series of other archaeological investigations conducted in downtown San Antonio (Bousman et al. 1995).

The lots selected for relocation lack archival evidence for structures except for the adobe building south of the Pereida House. Any structures previously occupying the remaining two lots would have been of insubstantial construction and therefore any traces would probably have been destroyed during the construction and clearing for HemisFair. The widening of South Alamo Street would have obliterated any traces of the adobe home that once faced upon the lot that is being considered for the relocation of the O.K. Bar; however, since the rear of that lot extended to the Alamo acequia, any support structure, privies, or cisterns might have been constructed near the middle of the lot or along the side property lines.

While background research indicates there is little probability that construction activities will disturb any significant historical sites or structures and thus none of the properties has significant archaeological potential, there is always the possibility of unrecorded remains being exposed. As indicated by the unexpected and extremely significant finds-including burials-in La Villita discovered by monitoring during the Fairmount Hotel move (Labadie 1986; Tennis 1994), the possibility of important portions of the city history may lie unrecorded within the area. Therefore, while no excavation or testing is recommended during this phase of construction, monitoring of construction activities should be conducted by qualified archaeologists during the moving of the structures and site preparation prior to their relocation to insure that no cultural resources are disturbed by this activity. If significant archaeological materials are discovered then plans to recover these remains can be initiated at that time. 


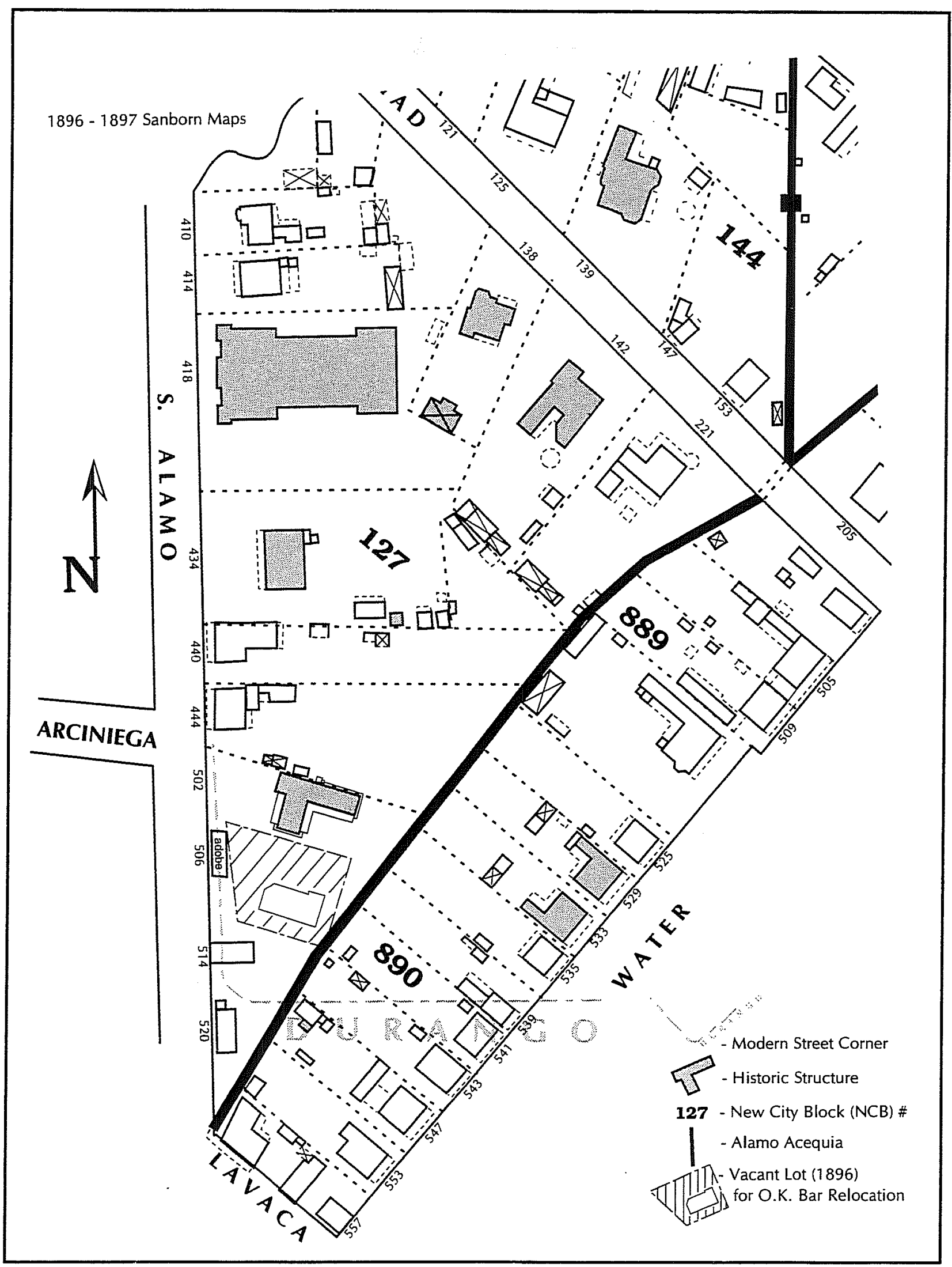

Figure 11. O.K. Bar relocation site. 


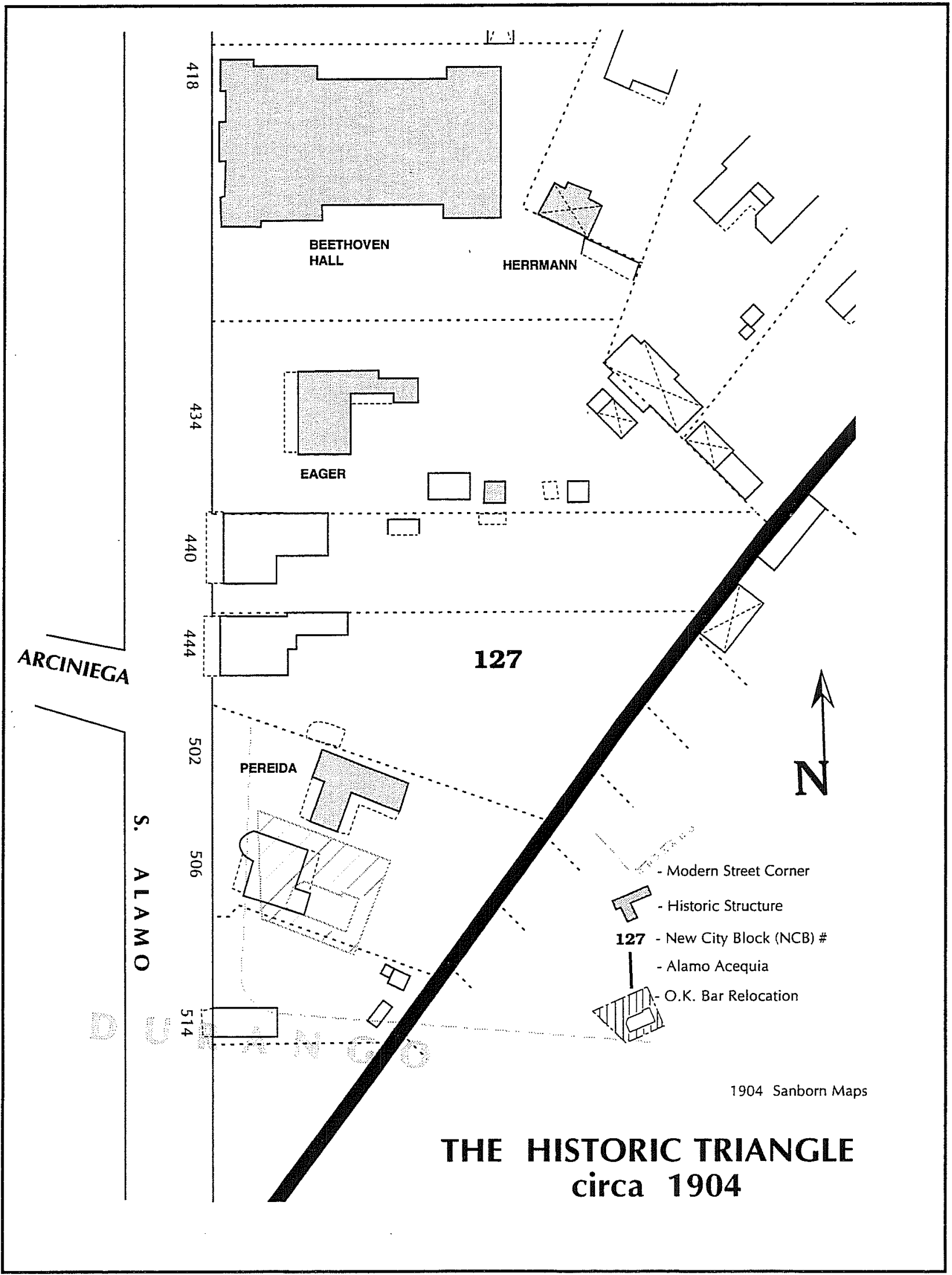

Figure 12. The Historic Triangle, ca. 1904. 


\section{REFERENCES CITED}

Bousman, C. B., A. A. Fox, K. J. Gross, and I. W. Cox

1995 Historical Archaeology in Downtown San Antonio, Texas: an Evaluation of Properties at the Proposed VIA Downtown Park and Ride Facility. Archaeological Survey Report, No. 240, Center for Archaeological Research, The University of Texas at San Antonio.

Chabot, F. C.

1937 With the Makers of San Antonio. Artes Graficas, San Antonio.

Cox, I. W.

1992 Archaeological Monitoring for the Tri-Party Improvements Project, San Antonio, Bexar County, Texas. Archaeological Survey Report, No. 204, Center for Archaeological Research, The University of Texas at San Antonio.

Cox, I. W., and A. A. Fox

1983 Literature and Archival Study for the Development of HemisFair Park, San Antonio, Texas. Manuscript on file, Center for Archaeological Research, The University of Texas at San Antonio.

de Paredes, M. S.

1727 Vista de las Misiones del Rio Grande del Norte pr Fr. Miguel Sevillano de Paredes en 15 de Octobre, 1727. Archivo General de Mexico: Historia, Volume 29. Center for American History, The University of Texas, Austin.

Fehrenbach, T. R.

1983 Lone Star: A History of Texas and the Texans. American Legacy Press, New York.

Fox, A. A

1985 Testing for the Location of the Alamo Acequia (41BX8) at Hemisfair Plaza, San Antonio, Texas. Archaeological Survey Report, No. 142, Center for Archaeological Research, The University of Texas at San Antonio.

Fox, A. A., and I. W. Cox

1990 Archaeological Excavations at the Alamo Acequia, Southwest Hemisfair Plaza, San Antonio, Bexar County, Texas. Archaeological Survey Report, No. 192, Center for Archaeological Research, The University of Texas at San Antonio.

Habig, M. A.

1968 The Alamo Chain of Missions: A History of San Antonio's Five Old Missions. Franciscan Press, Chicago.

1977 The Alamo Mission, San Antonio de Valero 1718-1793. Franciscan Herald Press, Chicago.

Hardin, S. L.

1994 Texian Iliad: A Military History of the Texas Revolution, 1835-1836. University of Texas Press, Austin. 
Labadie, J. H. (assembler)

1986 La Villita Earthworks (41BX677): San Antonio, Texas. A Preliminary Report of Investigations of Mexican Siege Works at the Battle of the Alamo. Archaeological Survey Report, No. 159, Center for Archaeological Research, The University of Texas at San Antonio.

Schuetz, M. K.

1970 Excavation of a Section of the Acequia Madre in Bexar County, Texas, and Archeological Investigations at Mission San Jose in April 1968. Archeological Report 19, Texas Historical Survey Committee, Austin.

Tennis, C. L.

1994 Evaluation of Archaeological Material from the Little Church of La Villita Property, San Antonio, Texas. Archaeological Survey Report, No. 228, Center for Archaeological Research, The University of Texas at San Antonio.

Walraven, B., and M. K. Walraven

1993 The Magnificent Barbarians, Little Told Tales of the Texas Revolution. Eakin Press, Austin.

Webb, W. P.(editor)

1952 The Handbook of Texas. Two volumes. The Texas Historical Association, Austin. 